\title{
Molecular analysis of volatile metabolites released specifically by staphylococcus aureus and pseudomonas aeruginosa
}

Wojciech Filipiak ${ }^{1,2+}$, Andreas Sponring ${ }^{1,2+}$, Maria Magdalena Baur ${ }^{1,2}$, Anna Filipiak ${ }^{1,2}$, Clemens Ager ${ }^{1,2}$, Helmut Wiesenhofer ${ }^{1,2}$, Markus Nagl $^{3}$, Jakob Troppmair ${ }^{4^{*}}$ and Anton Amann ${ }^{1,2^{*}}$

\begin{abstract}
Background: The routinely used microbiological diagnosis of ventilator associated pneumonia (VAP) is time consuming and often requires invasive methods for collection of human specimens (e.g. bronchoscopy). Therefore, it is of utmost interest to develop a non-invasive method for the early detection of bacterial infection in ventilated patients, preferably allowing the identification of the specific pathogens. The present work is an attempt to identify pathogen-derived volatile biomarkers in breath that can be used for early and non- invasive diagnosis of ventilator associated pneumonia (VAP). For this purpose, in vitro experiments with bacteria most frequently found in VAP patients, i.e. Staphylococcus aureus and Pseudomonas aeruginosa, were performed to investigate the release or consumption of volatile organic compounds (VOCs).
\end{abstract}

Results: Headspace samples were collected and preconcentrated on multibed sorption tubes at different time points and subsequently analyzed with gas chromatography mass spectrometry (GC-MS). As many as 32 and 37 volatile metabolites were released by $S$. aureus and $P$. aeruginosa, respectively. Distinct differences in the bacteria-specific VOC profiles were found, especially with regard to aldehydes (e.g. acetaldehyde, 3-methylbutanal), which were taken up only by $P$. aeruginosa but released by $S$. aureus. Differences in concentration profiles were also found for acids (e.g. isovaleric acid), ketones (e.g. acetoin, 2-nonanone), hydrocarbons (e.g. 2-butene, 1,10-undecadiene), alcohols (e.g. 2-methyl-1-propanol, 2-butanol), esters (e.g. ethyl formate, methyl 2-methylbutyrate), volatile sulfur compounds (VSCs, e.g. dimethylsulfide) and volatile nitrogen compounds (VNCs, e.g. 3-methylpyrrole). Importantly, a significant VOC release was found already 1.5 hours after culture start, corresponding to cell numbers of $\sim 8^{*} 10^{6}[\mathrm{CFUs} / \mathrm{ml}]$.

Conclusions: The results obtained provide strong evidence that the detection and perhaps even identification of bacteria could be achieved by determination of characteristic volatile metabolites, supporting the clinical use of breath-gas analysis as non-invasive method for early detection of bacterial lung infections.

Keywords: Volatile organic compounds (VOCs), Gas chromatography mass spectrometry (GCMS), Breath analysis In vitro headspace sampling, Adsorptive enrichment, Multibed sorption tubes, Volatile metabolites

Staphylococcus aureus, Pseudomonas aeruginosa

\footnotetext{
* Correspondence: jakob.troppmair@i-med.ac.at;

anton.amann@i-med.ac.at

${ }^{\dagger}$ Equal contributors

${ }^{4}$ Daniel-Swarovski Research Laboratory, Department of Visceral-, Transplant-

and Thoracic Surgery, Innsbruck Medical University, Innrain 66, A-6020,

Innsbruck, Austria

Full list of author information is available at the end of the article
} 


\section{Background}

Pneumonia is the most common cause of death related to infectious diseases. Even after aggressive antimicrobial treatment pneumococcal pneumonia causes mortalities of up to $10 \%$ [1]. Children and young adults are susceptible to lower respiratory tract infection typically caused by Staphylococcus aureus, Haemophilus influenzae and Pseudomonas aeruginosa [2]. Moreover, P. aeruginosa colonization of the lung is frequently found in cystic fibrosis patients, which worsens the prognosis of this disease [3]. Pneumonia signifcantly increases the average duration of intensive care unit (ICU) stays and mortality [4]. The diagnosis of nosocomial pneumonia often requires invasive and time consuming methods (e.g. bronchoscopy) [5]. Therefore, it is of utmost interest to develop a non-invasive method for the early diagnosis of this disease, preferably allowing the identification of the specific pathogens.

Attempts on screening of volatile bacterial metabolites for detection and classification of virulent bacteria was already undertaken in the past. However, the vast majority of studies on volatile organic compounds (VOCs) released from bacteria included qualitative analyses only [6-10]. Also direct mass spectrometric methods were used for the investigation of VOC release, comprising selected ion flow tube mass spectrometry (SIFT-MS) $[11,12]$ and proton transfer reaction mass spectrometry (PTR-MS) [13-15]. However, especially in the case of PTR-MS the identification of VOCs is questionable, since several compounds may undergo fragmentation and contribute to one $\mathrm{m} / z$ signal $[16,17]$. Nevertheless, encouraging results were already reported, showing that some microorganisms have their own expression patterns of enzymes, producing a characteristic range of volatile metabolites [18-21]. This prompted us to further develop exhaled breath analysis for the diagnosis of bacterial lung infections [22,23]. Although changes in the VOC patterns in breath have not been extensively investigated so far, detection of bacterial infections by exhaled air analysis has been proposed by sensor technology $[24,25]$. This approach is still in its infancy and often under critical review due to the use of complex mathematical pattern recognition instead of clear identification of specific VOCs. Sensor systems such as the electronic nose systems (EN) are often unspecific and do generate a pattern of responses for the sensors. Neuronal network algorithms or principal component analyses are applied and have been used in separating training groups with known disease. Testing for unknown samples has not been very successful yet $[24,25]$. Much more convincing results were obtained by Scott-Thomas et al. [26], where 2-aminoacetophenone (2-AA) was measured by gas chromatography mass spectrometry (GC-MS) in cystic fibrosis patients $(\mathrm{CF})$ as volatile biomarker produced by
P. aeruginosa, which was also confirmed by other researchers [27-30]. Significantly higher levels of 2aminoacetophenone were found in exhaled breath of cystic fibrosis patients colonized with $P$. aeruginosa while the concentration of this metabolite was below the detection limit in both control groups (healthy subjects and CF patients colonized with other bacteria species). Encouraging results were obtained in other studies, where specific volatile biomarkers of Aspergillus spp. were detected in exhaled breath of tuberculosis patients colonized with Mycobacterium tuberculosis cells [21,3134].

The aim of this study is to characterize the release or consumption of VOCs by $S$. aureus and $P$. aeruginosa. Headspace samples from cultures of both pathogens were collected and preconcentrated on multibed sorption tubes and analyzed by GC-MS. Sampling was done under strictly controlled ventilation conditions at several time points to follow the dynamic changes in temporal VOC concentration profiles.

\section{Results \\ GC-MS analysis}

The initial amount of cells in the fermenters amounted to $4.04 \times 10^{5} \pm 2.75 \times 10^{5}$ colony forming units $\left(\mathrm{CFUs} \mathrm{ml}^{-1}\right.$ ) for S. aureus $(\mathrm{n}=5)$ and $2.2 \times 10^{6} \pm 5.1 \times 10^{5} \mathrm{CFUs}^{*} \mathrm{ml}^{-1}$ for $P$. aeruginosa $(\mathrm{n}=7)$. The average cell densities and ODs at $600 \mathrm{~nm}$ are presented in Table 1. For both tested species all headspace samples were collected within the logarithmic phase of microbial proliferation. Importantly, bronchoalveolar lavage (BAL) studies have typically used a diagnostic threshold of $10^{4}$ or $10^{5} \mathrm{CFU} / \mathrm{ml}$ to define both the presence of pneumonia and the etiologic pathogen [35]. Naturally, the real number of bacteria in lungs is higher since a 10-fold dilution of BAL samples and the large surface area of the alveolar zone have to be considered.

A high number of different VOCs were found to be released by both bacterial species in a concentration range varying from part per trillion $\left(\mathrm{ppt}_{\mathrm{v}}\right)$ to part per million $\left(\mathrm{ppm}_{\mathrm{v}}\right)$. Also several volatile compounds were consumed by the bacteria, particularly by $P$. aeruginosa (Tables 2 and $3 \mathrm{~B}$, Figure 1b). S. aureus released $32 \mathrm{VOCs}$ of diverse chemical classes amongst which 28 were analyzed in Selected Ion Monitoring mode (SIM) and 4 in Total Ion Chromatogram mode (TIC), comprising 9 aldehydes, 4 alcohols, 3 ketones, 2 acids, 2 sulphur containing compounds, 6 esters and 6 hydrocarbons. Only benzaldehyde was found in decreased concentrations in S. aureus cultures compared to medium controls.

P. aeruginosa released 37 VOCs (32 VOCs analyzed in SIM mode and 5 VOCs analyzed in TIC mode) but mostly in lower amounts than S. aureus. Altogether 12 compounds were consumed by $P$. aeruginosa ( 9 VOCs analyzed in SIM mode and 3 VOCs analyzed in TIC 
Table 1 Average CFUs* $\mathrm{ml}^{-1}$ and $\mathrm{OD}_{600}$ of $\mathrm{S}$. aureus cultures at different incubation times

\begin{tabular}{|c|c|c|c|c|c|c|c|c|}
\hline \multirow[b]{3}{*}{ Time point } & \multicolumn{4}{|c|}{$\mathrm{cfu}^{*} \mathrm{ml}^{-1}$} & \multicolumn{4}{|c|}{ optical density $600 \mathrm{~nm}$} \\
\hline & \multicolumn{2}{|c|}{ S. aureus } & \multicolumn{2}{|c|}{$P$. aeruginosa } & \multicolumn{2}{|c|}{ S. aureus } & \multicolumn{2}{|c|}{ P. aeruginosa } \\
\hline & average & stdev & average & stdev & average & stdev & average & stdev \\
\hline $\mathrm{Oh}$ & $4.04 \mathrm{E}+5$ & $2.75 E+5$ & $2.17 \mathrm{E}+06$ & $5.13 E+05$ & 0.0291 & 0.0134 & 0.047 & 0.008 \\
\hline $1 \mathrm{~h} 30 \mathrm{~m}$ & $2.38 \mathrm{E}+6$ & $1.63 E+6$ & $9.76 \mathrm{E}+06$ & $3.33 \mathrm{E}+06$ & 0.0349 & 0.0111 & 0.051 & 0.005 \\
\hline $2 \mathrm{~h} 15 \mathrm{~m}$ & - & - & $1,83 \mathrm{E}+07$ & $6.13 E+06$ & - & - & 0.058 & 0.005 \\
\hline $3 \mathrm{~h} 00 \mathrm{~m}$ & $7.38 \mathrm{E}+6$ & $3.73 E+6$ & $6.17 \mathrm{E}+07$ & $2.33 \mathrm{E}+07$ & 0.0652 & 0.0076 & 0.066 & 0.005 \\
\hline $3 \mathrm{~h} 45 \mathrm{~m}$ & - & - & $1.18 \mathrm{E}+08$ & $6.32 \mathrm{E}+07$ & - & - & 0.077 & 0.012 \\
\hline $4 \mathrm{~h} 30 \mathrm{~m}$ & $4.95 E+7$ & $2.91 E+7$ & $1.61 E+08$ & $7.35 E+07$ & 0.1814 & 0.0190 & 0.088 & 0.012 \\
\hline $5 \mathrm{~h} 15 \mathrm{~m}$ & - & - & $1.83 E+08$ & $8.12 \mathrm{E}+07$ & - & - & 0.097 & 0.012 \\
\hline $6 \mathrm{~h} 00 \mathrm{~m}$ & $1.30 \mathrm{E}+8$ & $4.52 E+7$ & $2.91 E+08$ & $1.19 E+08$ & 0.2531 & 0.0085 & 0.101 & 0.015 \\
\hline $24 \mathrm{~h} 00 \mathrm{~m}$ & - & - & $2.31 E+09$ & $1.02 E+09$ & - & - & 0.511 & 0.138 \\
\hline $26 \mathrm{~h} 00 \mathrm{~m}$ & - & - & $4.64 E+09$ & $1.35 E+09$ & - & - & 0.813 & 0.133 \\
\hline $28 \mathrm{~h} 00 \mathrm{~m}$ & - & - & $5.91 E+09$ & $2.46 \mathrm{E}+09$ & - & - & 0.892 & 0.109 \\
\hline
\end{tabular}

mode), compared to only benzaldehyde consumed by $S$. aureus. The higher proliferation rates of $P$. aeruginosa cultures were found, and the respective CFU counts were still strongly increasing at the second day of incubation; hence the headspace sampling was performed also on day two after 24, 26 and $28 \mathrm{~h}$ of microbial growth. Six classes of compounds were found, comprising 9 hydrocarbons ( 8 with determined concentrations), 3 nitrogen containing compounds ( 2 with determined concentrations), 8 esters ( 3 with determined concentrations), 7 ketones (6 with determined concentrations), 7 sulphur containing compounds( 4 with determined concentrations) and 3 alcohols (2 with determined concentrations). Decreased concentrations were measured for 12 compounds, including 11 aldehydes and 1 ketone (2,3-butanedione).

\section{Aldehydes}

One of the most striking observations was the completely opposite behaviour with regard to this chemical class when comparing the two species: S. aureus released various aldehydes (Figure 1a), partly in high concentrations, while no release of aldehydes was observed for $P$. aeruginosa. (Table 3B, Figure 1b). Particularly 3-methylbutanal (Figure 1a), 2- methylpropanal, acetaldehyde and (Z)-2methyl-2-butenal were found in strongly elevated concentrations in the headspace of $S$. aureus cultures. These four aldehydes increased to significant concentrations at early time points (1.5-3 h of incubation), hence at relatively low cell densities of the bacteria culture.

\section{Alcohols}

Alcohols were produced by both bacteria species (Table 2 and $3 \mathrm{~A}$ ) and they were one of the most prominently released compounds in $S$. aureus. Especially ethanol was present in high concentrations at an early stage in the headspace of both bacteria. Besides, also 1-butanol, 2- methyl-1- propanol and 3-methyl-1-butanol were detected at significantly higher amounts at the earliest after $4.5 \mathrm{~h}$ of $S$. aureus growth. However, among the three alcohols released by $P$. aeruginosa only ethanol was present at significant levels on day one ( $<24 \mathrm{~h}$ since inoculation), while 3-methyl-1-butanol and 2-butanol reached significantly higher concentrations on the second day of the experiment.

\section{Ketones}

Amongst three ketones released by S. aureus, acetoin (hydroxybutanone) (Figure 1c) and acetol (hydroxacetone) were found at higher concentration levels than 2,3-butanedione, which was observed at elevated concentration already in control samples. Acetoin was significantly released already after $1.5 \mathrm{~h}$ reaching high levels at $4.5 \mathrm{~h}$ and $6 \mathrm{~h}$ after inoculation, whereas the release of butanedione was weaker especially if the substantial background originating from the medium is considered.

Importantly, entirely different ketones were released by $P$. aeruginosa, comprising 2 - butanone, 2-pentanone, methyl isobutyl ketone, 2-heptanone, 4-heptanone, 3octanone and 2-nonanone (Figure 1d). Although they were found at relatively low concentrations, most of them were absent in medium controls (apart from 2butanone and methyl isobutyl ketone).

With respect to breath gas analysis 2-nonanone is presumably the most interesting ketone released by $P$. aeruginosa due to its absence in medium controls and early significant appearance in bacteria cultures. Moreover, concentrations of 2-nonanone determined, correlated very well with the proliferation rate of $P$. aeruginosa.

\section{Acids and esters}

Two acids were produced by S. aureus, isovaleric acid and acetic acid. Particularly prominent was the release of acetic 
Table 2 Median concentrations of VOCs released or consumed by Staphylococcus aureus

\begin{tabular}{|c|c|c|c|c|c|c|c|}
\hline \multirow[b]{2}{*}{ Compound } & \multirow[b]{2}{*}{ CAS } & \multirow[b]{2}{*}{$\mathrm{m} / \mathrm{z}$ for SIM } & \multicolumn{5}{|c|}{ median concentrations [ppbv] } \\
\hline & & & medium & $1.5 \mathrm{~h}$ & $3.0 \mathrm{~h}$ & $4.5 \mathrm{~h}$ & $6.0 \mathrm{~h}$ \\
\hline propanal & $123-38-6$ & 57 & 3.955 & 10.62 & 14.22 & 8.932 & 7.04 \\
\hline 3-methyl-2-butenal & 107-86-8 & 55,84 & 1.526 & 1.832 & 3.415 & 5.708 & 5.348 \\
\hline 2-ethylacrolein & $922-63-4$ & 84 & 1.656 & 2.01 & 6.453 & 5.537 & 5.775 \\
\hline (Z)-2-methyl-2-butenal & $1115-11-3$ & 84 & 73.48 & 81.91 & 177.4 & 268.5 & 247.9 \\
\hline (E)-2-methyl-2-butenal & 497-03-0 & 84 & $<\mathrm{LOD}$ & $<\mathrm{LOD}$ & 0.259 & 0.394 & 0.381 \\
\hline benzaldehyde ${ }^{\S}$ & $100-52-7$ & 107 & 20.64 & 19.08 & 17.65 & 12.66 & 3.815 \\
\hline methacrolein & $78-85-3$ & 70 & 5.922 & 5.644 & 9.328 & 7.617 & 6.36 \\
\hline acetaldehyde & $75-07-0$ & 43 & 528.5 & 606.4 & 374.2 & 1022.7 & 1417.4 \\
\hline 3-methylbutanal ** & $590-86-3$ & - & 317.1 & 403.3 & 2764.3 & 4779.3 & 4818.5 \\
\hline 2-methylpropanal ** & $78-84-2$ & - & 598.6 & 658.5 & 2044.5 & 1698.6 & 1299.5 \\
\hline 1-butanol & $71-36-3$ & 56 & $<\mathrm{LOD}$ & $<\mathrm{LOD}$ & $<\mathrm{LOD}$ & 21.24 & 59.4 \\
\hline 2-methyl-1-propanol & 78-83-1 & 56,74 & 0 & 0 & 0 & 21.32 & 52.62 \\
\hline 3-methyl-1-butanol & $123-51-3$ & 55,70 & 0 & 0 & 0 & 27.65 & 210.0 \\
\hline ethanol ** & $64-17-5$ & - & 0 & 89.57 & 237.0 & 6173.0 & 11695.1 \\
\hline acetoin (hydroxybutanone) & 513-86-0 & 88 & $<\mathrm{LOD}$ & 3.59 & 8.004 & 140.6 & 279.3 \\
\hline acetol (hydroxyacetone) & 116-09-6 & 74 & $<\mathrm{LOD}$ & $<\mathrm{LOD}$ & $<\mathrm{LOD}$ & 113.5 & 331.0 \\
\hline 2,3-butanedione & $431-03-8$ & 86 & 22.65 & 23.92 & 27.45 & 49.84 & 67.99 \\
\hline acetic acid & 64-19-7 & 45,60 & 0 & 0 & 0 & 880.5 & 2566.6 \\
\hline isovaleric acid & $503-74-2$ & 60 & 0 & 0 & 0 & 31.13 & 97.35 \\
\hline ethyl acetate & 141-78-6 & 61 & 0 & 0 & 0 & 1.973 & 5.624 \\
\hline n-butyl acetate & $123-86-4$ & 56,73 & 0 & 0 & 0 & 0 & 0.239 \\
\hline ethyl isovalerate & $108-64-5$ & 70 & 0 & 0 & 0 & $<\mathrm{LOD}$ & 0.852 \\
\hline isopentyl acetate & $123-92-2$ & 55,70 & 0 & 0 & 0 & $<\mathrm{LOD}$ & 1.938 \\
\hline ethyl formate & 109-94-4 & 31 & 0 & 0 & 0 & $<\mathrm{LOD}$ & 3.188 \\
\hline methyl methacrylate ** & $80-62-6$ & - & 15.99 & 14.79 & 20.27 & 28.65 & 31.93 \\
\hline methanethiol & $74-93-1$ & 47 & 134.2 & 210.4 & 360.6 & 559.4 & 701.5 \\
\hline dimethyldisulfide (DMDS) & $624-92-0$ & 94 & 1.558 & 2.221 & 3.657 & 8.134 & 10.24 \\
\hline 1,3-butadiene & 106-99-0 & 54 & $<\mathrm{LOD}$ & $<\mathrm{LOD}$ & 4.941 & 4.342 & 4.313 \\
\hline 2-methylpropene & 115-11-7 & 56 & $<\mathrm{LOD}$ & $<\mathrm{LOD}$ & 4.546 & 14.31 & 21.89 \\
\hline n-butane & 106-97-8 & 58 & 0.664 & 0.703 & 1.274 & 2.504 & 4.329 \\
\hline (Z)-2-butene & 590-18-1 & 56 & 0 & 0 & $<\mathrm{LOD}$ & 3.687 & 4.789 \\
\hline (E)-2-butene & 624-64-6 & 56 & 1.344 & $<\mathrm{LOD}$ & 4.793 & 11.32 & 13.73 \\
\hline propane & $74-98-6$ & 43,41 & 0.91 & 0.815 & 1.951 & 3.441 & 4.902 \\
\hline
\end{tabular}

Bold numbers indicate significant difference (Kruskal-Wallis test) in VOC concentrations between bacteria cultures and medium headspace ( $\mathrm{p}<0.05$ ). Ethanol, 2-methylpropanal, 3- methylbutanal and methyl methacrylate were analyzed in TIC mode as indicated by **, while the remaining compounds were analyzed in SIM mode. Number of independent experiments $n=5$ for each time point of bacteria growth, $n=14$ for all medium controls. Concentrations are given in ppb $b_{v}$ $\S$ uptake (decreased concentration).

acid, which reached over $2500 \mathrm{ppb}_{\mathrm{v}}$ (i.e. $2.5 \mathrm{ppm}_{\mathrm{v}}$ ) within only $6 \mathrm{~h}$ of bacterial growth (Table 2). It should be noted that none of these acids was found in the headspace of the medium controls. In contrast, no acids at all were released by $P$. aeruginosa.

All esters released by bacteria tested were detected in low concentrations and at relatively late time points with the exception of methyl methacrylate. Nevertheless, background concentrations of esters are comparatively high and not stable. Therefore, esters seem to have no value in breath analysis in infections caused by these pathogens.

Volatile sulphur-containing compounds (VSCs)

Two volatile sulphur-containing compounds (VSCs) were found to be released from S. aureus, dimethyldisulfide 
Table 3 A and B: Median concentrations of VOCs released (A) or taken up (B) by Pseudomonas aeruginosa

\begin{tabular}{|c|c|c|c|c|c|c|c|c|c|c|c|c|c|}
\hline Compound & CAS & $\mathrm{m} / \mathrm{z}$ for SIM & M [ppbv] & $1.5(n=3)$ & $2.25(n=4)$ & $3(n=4)$ & $3.75(n=5)$ & $4.5(n=5)$ & $5.20(n=4)$ & $6(n=6)$ & $24(n=5)$ & $26(n=4)$ & $28(n=3)$ \\
\hline \multicolumn{14}{|l|}{ A) } \\
\hline $\begin{array}{l}\text { 3-methyl- } \\
\text { 1-butanol }\end{array}$ & $123-51-3$ & 55,70 & $<\mathrm{LOD}$ & $<\mathrm{LOD}$ & $<\mathrm{LOD}$ & $<\mathrm{LOD}$ & $<\mathrm{LOD}$ & $<\mathrm{LOD}$ & $<\mathrm{LOD}$ & $<\mathrm{LOD}$ & 62.56 & 148.4 & 142.2 \\
\hline ethanol* & $64-17-5$ & - & 102.1 & 623.5 & 322.2 & 396.4 & 441.4 & 548.9 & 800.0 & 761.6 & 203.1 & 333.3 & 350.4 \\
\hline 2-butanol ${ }^{\#}$ & $78-92-2$ & 45 & 0 & 0 & 0 & 0 & 0 & 0 & 0 & 0 & 0 & $1.5 E+04$ & $8.5 E+03$ \\
\hline 2-nonanone & $821-55-6$ & $43,56,71$ & $<L O D$ & 1.091 & 1.586 & 3.855 & 6.372 & 10.29 & 15.33 & 14.83 & 12.24 & 21.82 & 22.42 \\
\hline 2-pentanone & $107-87-9$ & 43,86 & $<L O D$ & $<\mathrm{LOD}$ & $<L O D$ & $<L O D$ & $<L O D$ & 0.526 & 0.910 & 0.901 & 12.91 & 19.30 & 17.94 \\
\hline 2-heptanone & $110-43-0$ & 43,71 & n.d. & $<\mathrm{LOD}$ & $<\mathrm{LOD}$ & $<\mathrm{LOD}$ & $<\mathrm{LOD}$ & $<\mathrm{LOD}$ & 0.286 & 0.259 & 2.700 & 4.789 & 3.622 \\
\hline 4-heptanone & $123-19-3$ & 43,71 & n.d. & n.d. & n.d. & n.d. & n.d. & $<\mathrm{LOD}$ & 0.422 & 0.496 & 1.000 & 2.079 & 1.088 \\
\hline 3-octanone* & $106-68-3$ & - & n.d. & n.d. & n.d. & n.d. & n.d. & n.d. & n.d. & $<\mathrm{LOD}$ & 0.557 & 0.817 & $<\mathrm{LOD}$ \\
\hline 2-butanone* & 78-93-3 & - & 10.08 & 25.49 & 23.57 & 15.89 & 17.90 & 17.11 & 19.39 & 14.65 & 30.39 & 40.55 & 40.03 \\
\hline $\begin{array}{l}\text { methyl isobutyl } \\
\text { ketone }^{\#}\end{array}$ & 108-10-1 & 85,100 & $3.8 \mathrm{E}+04$ & $8.7 E+04$ & $8.0 \mathrm{E}+04$ & $5.5 \mathrm{E}+04$ & $7.9 E+04$ & $6.5 E+04$ & $7.6 E+04$ & $6.4 \mathrm{E}+04$ & $2.3 E+05$ & $3.8 E+05$ & $2.7 \mathrm{E}+05$ \\
\hline ethyl acetate & 141-78-6 & 61 & $<\mathrm{LOD}$ & 1.936 & 1.123 & 0.777 & 1.556 & 1.167 & 1.088 & 1.231 & 1.972 & 2.686 & 1.895 \\
\hline $\begin{array}{c}\text { methyl } \\
\text { 2-methylbutyrate }\end{array}$ & $868-57-5$ & 56,85 & n.d. & n.d. & n.d. & n.d. & n.d. & n.d. & n.d. & n.d. & n.d. & 0.637 & 1.669 \\
\hline $\begin{array}{c}\text { methyl } \\
\text { methacrylate* }\end{array}$ & $80-62-6$ & - & 24.81 & 38.14 & 44.49 & 32.28 & 44.03 & 36.81 & 46.67 & 38.67 & 47.72 & 54.17 & 48.13 \\
\hline $\begin{array}{c}\text { ethyl } \\
\text { 2-methylbutyrate }\end{array}$ & 7452-79-1 & $57,74,85$ & 0 & 0 & 0 & 0 & 0 & 0 & 0 & 0 & $7.5 E+04$ & $1.4 E+05$ & $1.8 E+05$ \\
\hline $\begin{array}{l}\text { 2-methylbutyl } \\
\text { isobutyrate }^{\#}\end{array}$ & $2445-69-4$ & 55,70 & 0 & 0 & 0 & 0 & 0 & 0 & 0 & 0 & $5.2 E+05$ & $1.2 E+06$ & $1.3 E+06$ \\
\hline isoamyl butyrate ${ }^{\#}$ & $106-27-4$ & 43,71 & 0 & 0 & 0 & 0 & 0 & 0 & 0 & 0 & $2.5 E+05$ & $1.4 E+06$ & $7.6 E+05$ \\
\hline $\begin{array}{l}\text { 2-methylbutyl } \\
\text { 2-methylbutyrate }\end{array}$ & $2445-78-5$ & $57,70,85$ & 0 & 0 & 0 & 0 & 0 & 0 & 0 & 0 & $2.7 E+06$ & $7.6 E+06$ & $9.7 E+06$ \\
\hline amyl isovalerate & $25415-62-7$ & $57,70,85$ & 0 & 0 & 0 & 0 & 0 & 0 & 0 & 0 & $1.9 E+06$ & $3.9 E+06$ & $6.1 E+06$ \\
\hline $\begin{array}{l}\text { dimethyl sulfide } \\
\text { (DMS) }\end{array}$ & $75-18-3$ & 47,62 & $<\mathrm{LOD}$ & $<\mathrm{LOD}$ & $<\mathrm{LOD}$ & n.d. & $<\mathrm{LOD}$ & $<\mathrm{LOD}$ & $<\mathrm{LOD}$ & 1.295 & 99.54 & 143.0 & 173.6 \\
\hline $\begin{array}{l}\text { Dimethyl disulfide } \\
\text { (DMDS) }\end{array}$ & $624-92-0$ & 94 & 0.580 & 1.817 & 1.042 & 0.663 & 0.605 & 0.538 & 0.600 & 0.597 & 5.909 & 14.11 & 11.09 \\
\hline $\begin{array}{l}\text { dimethyl trisulfide } \\
\text { (DMTS) }\end{array}$ & $3658-80-8$ & 126 & $<\mathrm{LOD}$ & $<\mathrm{LOD}$ & $<\mathrm{LOD}$ & $<\mathrm{LOD}$ & $<\mathrm{LOD}$ & $<\mathrm{LOD}$ & $<\mathrm{LOD}$ & $<\mathrm{LOD}$ & 0.324 & 0.764 & 1.106 \\
\hline methanethiol & 74-93-1 & 47 & 33.03 & 45.55 & 47.77 & 21.86 & 21.31 & 18.22 & 25.25 & 24.64 & 261.2 & 418.0 & 318.1 \\
\hline mercaptoacetone $\mathrm{e}^{\#}$ & $24653-75-6$ & 90 & 0 & 0 & 0 & 0 & 0 & 0 & 0 & 0 & $1.7 E+05$ & $2.6 E+05$ & $2.1 E+05$ \\
\hline $\begin{array}{l}\text { 2-methoxy- } \\
\text { 5-methylthiophene }\end{array}$ & $31053-55-1$ & 113 & 0 & 0 & 0 & 0 & 0 & 0 & 0 & 0 & $1.1 E+06$ & $2.0 E+06$ & $1.6 E+06$ \\
\hline
\end{tabular}


Table 3 A and B: Median concentrations of VOCs released (A) or taken up (B) by Pseudomonas aeruginosa (Continued)

\begin{tabular}{|c|c|c|c|c|c|c|c|c|c|c|c|c|c|}
\hline $\begin{array}{l}\text { 3-(ethylthio)- } \\
\text { propanal }^{\#}\end{array}$ & $5454-45-5$ & 62 & 0 & 0 & 0 & 0 & 0 & 0 & 0 & 0 & $5.1 E+04$ & $3.2 E+05$ & $7.9 E+05$ \\
\hline 1-undecene & $821-95-4$ & $41,55,69$ & 0.337 & 3.687 & 4.891 & 7.566 & 15.30 & 27.24 & 49.10 & 58.73 & 317.5 & 296.1 & 245.0 \\
\hline $\begin{array}{l}\text { 2-methyl- } \\
\text { 2-butene }\end{array}$ & 513-35-9 & 55,70 & $<\mathrm{LOD}$ & $<\mathrm{LOD}$ & $<\mathrm{LOD}$ & 0.138 & 0.221 & 0.324 & 0.492 & 0.651 & 0.524 & 0.512 & 0.406 \\
\hline 1,10-undecadiene & $13688-67-0$ & $41,55,69$ & $<\mathrm{LOD}$ & $<\mathrm{LOD}$ & $<\mathrm{LOD}$ & $<\mathrm{LOD}$ & $<\mathrm{LOD}$ & 0.516 & 0.838 & 0.993 & 6.813 & 6.349 & 4.515 \\
\hline 1-nonene & $124-11-8$ & $55,70,126$ & 0.269 & 0.419 & 0.336 & 0.299 & 0.370 & 0.419 & 0.541 & 0.588 & 2.613 & 3.401 & 2.623 \\
\hline 1-decene & $872-05-9$ & 55,70 & $<\mathrm{LOD}$ & $<\mathrm{LOD}$ & 0.283 & 0.207 & 0.203 & 0.221 & 0.289 & 0.325 & 1.178 & 1.213 & 0.910 \\
\hline 1-dodecene & $112-41-4$ & $57,70,85$ & 1.861 & 4.596 & 3.341 & 2.211 & 3.221 & 2.017 & 3.148 & 2.646 & 9.494 & 9.129 & 8.242 \\
\hline butane & $106-97-8$ & 58 & 0.331 & 0.471 & 0.283 & 0.160 & 0.143 & 0.154 & 0.275 & 0.184 & 0.673 & 1.482 & 1.400 \\
\hline isoprene $^{*}$ & $78-79-5$ & - & $<L O D$ & 2.110 & 3.156 & 7.121 & 10.28 & 12.25 & 14.77 & 16.80 & 20.40 & 20.09 & 12.47 \\
\hline $\begin{array}{c}\text { 10-methyl- } \\
\text { 1-undecene\# }\end{array}$ & $22370-55-4$ & $57,70,85$ & 0 & 0 & 0 & 0 & 0 & 0 & 0 & 0 & $3.3 E+05$ & $3.2 E+05$ & $2.9 E+05$ \\
\hline pyrrole & 109-97-7 & 41,67 & 1.105 & 29.62 & 48.16 & 49.66 & 39.84 & 20.50 & 22.59 & 13.12 & 15.55 & 21.01 & 17.50 \\
\hline 3-methylpyrrole* & $616-43-3$ & - & $<\mathrm{LOD}$ & $<\mathrm{LOD}$ & $<\mathrm{LOD}$ & $<\mathrm{LOD}$ & $<\mathrm{LOD}$ & $<\mathrm{LOD}$ & 5.272 & 8.278 & 24.74 & 24.57 & 18.92 \\
\hline 1-vinyl aziridine ${ }^{\#}$ & 5628-99-9 & 41,67 & 0 & $2.3 E+07$ & $2.8 E+07$ & $2.1 E+07$ & $1.1 E+07$ & $4.8 E+06$ & $3.5 E+06$ & $1.1 E+06$ & $5.0 E+04$ & $4.6 E+05$ & 0 \\
\hline \multicolumn{14}{|l|}{ B) } \\
\hline butanedione & 431-03-8 & 86 & 77.22 & 122.9 & 112.9 & 57.27 & 50.76 & 24.49 & 22.30 & 9.568 & 5.131 & 7.535 & 8.746 \\
\hline benzaldehyde & $100-52-7$ & 107 & 183.9 & 145.2 & 102.2 & 26.50 & 13.11 & 9.944 & 9.434 & 7.024 & 5.698 & 7.082 & 8.538 \\
\hline acetaldehyde & $75-07-0$ & 43 & 515.5 & 340.6 & 316.1 & 65.15 & 47.75 & 53.22 & 87.89 & 87.14 & 30.84 & 42.56 & 22.97 \\
\hline methacroleian & $78-85-3$ & 70 & 3.291 & 4.175 & 3.237 & 0.922 & 0.502 & 0.209 & 0.187 & $<L O D$ & $<L O D$ & $<L O D$ & $<L O D$ \\
\hline 3-methylbutanal* & $590-86-3$ & - & 419.6 & 832.1 & 620.1 & 191.3 & 126.8 & 45.23 & 37.63 & 14.52 & 24.89 & 57.25 & 41.17 \\
\hline nonanal & $124-19-6$ & $43,58,71$ & 13.44 & 9.317 & 8.969 & 6.332 & 7.285 & 7.379 & 7.397 & 6.608 & 4.122 & 6.176 & 6.222 \\
\hline propanal & $123-38-6$ & 57 & 2.944 & 3.382 & 2.222 & 0.958 & 1.132 & 0.967 & 1.112 & 0.863 & $<L O D$ & $<L O D$ & $<L O D$ \\
\hline $\begin{array}{l}\text { 3-methyl- } \\
\text { 2-butenal }\end{array}$ & $107-86-8$ & 55,84 & 1.266 & 1.578 & 1.617 & 0.953 & 0.856 & 0.641 & 0.515 & $<L O D$ & $<L O D$ & $<\mathbf{L O D}$ & n.d. \\
\hline acrolein & $107-02-8$ & 56 & 9.951 & 7.257 & 11.23 & 9.622 & 6.918 & 7.082 & 9.965 & 7.432 & 4.036 & 3.915 & 3.628 \\
\hline butanal* & $123-72-8$ & - & 24.35 & 22.71 & 11.00 & 1.305 & $<L O D$ & 1.129 & 1.837 & 2.259 & $<L O D$ & $<L O D$ & $<L O D$ \\
\hline 2-methylpropanal* & $78-84-2$ & - & 181.9 & 273.3 & 199.8 & 80.03 & 28.30 & 11.41 & 7.520 & 4.378 & 4.057 & 6.026 & 4.851 \\
\hline octanal* & $124-13-0$ & - & 5.424 & 4.226 & 4.282 & 3.410 & 2.448 & 2.507 & 3.011 & 1.791 & 1.266 & 1.950 & 2.580 \\
\hline
\end{tabular}

Bold numbers indicate significant difference (Kruskal-Wallis test) between VOC concentrations in bacteria cultures and medium $(\mathrm{m})$ headspace $(\mathrm{p}<0.05)$. * TIC mode analysis with determined concentrations (ppb) and ${ }^{\#}$ SIM mode analysis semi-quantified by peak area, $\mathrm{n}=32$ for medium control. 


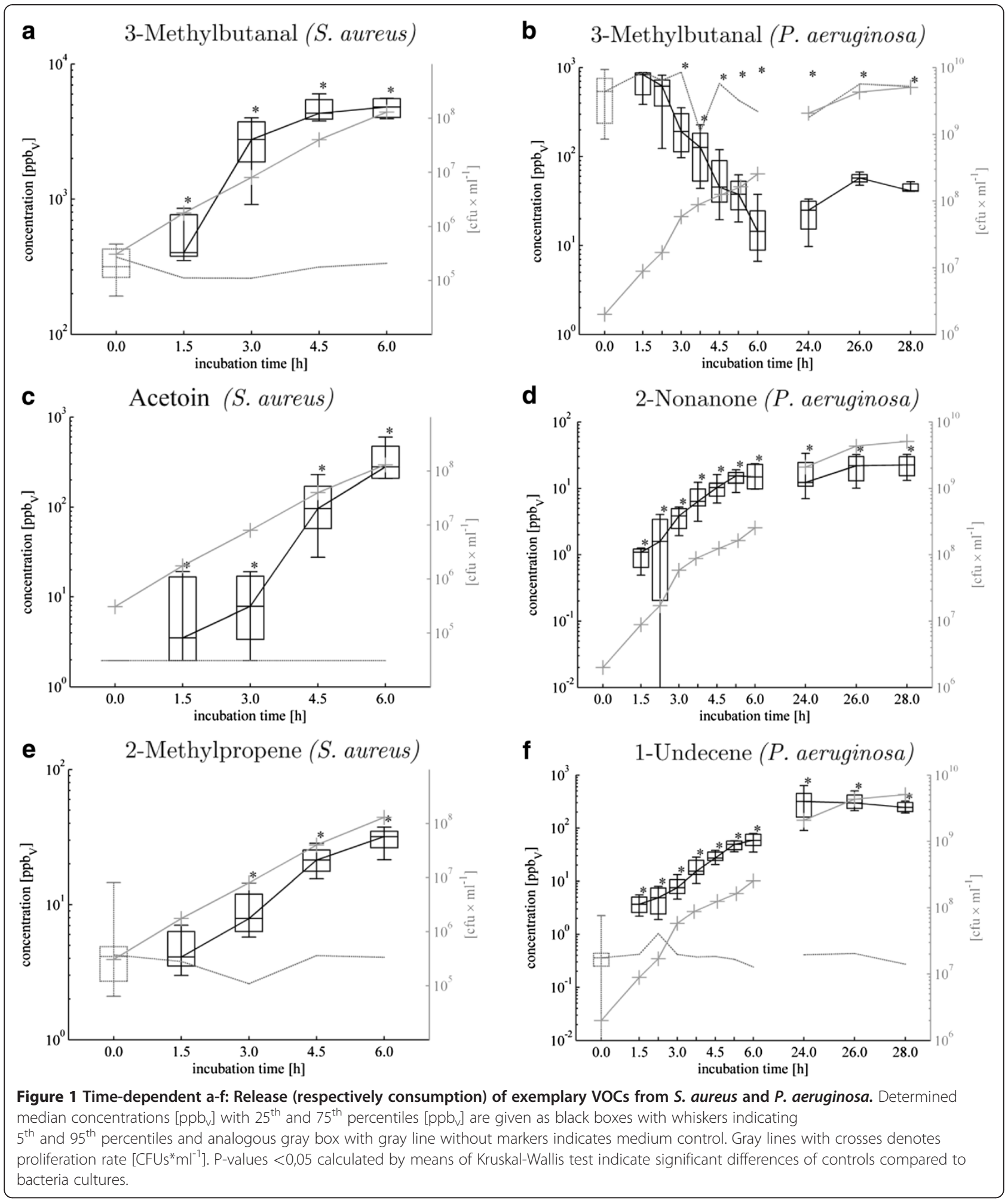

(DMDS) and methanethiol (MeSH). The later one was detected at significantly higher concentrations already $1.5 \mathrm{~h}$ after inoculation and reached over $700 \mathrm{ppb}_{\mathrm{v}}$ after $6 \mathrm{~h}$ of bacteria growth. Both VSCs were also released by $P$. aeruginosa but at substantially lower concentrations reaching $\sim 0.6 \mathrm{ppb}_{\mathrm{v}}$ of DMDS and $\sim 25 \mathrm{ppb}_{\mathrm{v}}$ of MeSH $6 \mathrm{~h}$ after inoculation (increased to $\sim 11 \mathrm{ppb}_{\mathrm{v}}$ and $\sim 320 \mathrm{ppb}_{\mathrm{v}}$, respectively, $28 \mathrm{~h}$ after inoculation).

Additionally, dimethylsulfide (DMS), dimethyltrisulfide (DMTS), mercaptoacetone, 3-(ethylthio)-propanal 
and 2-methoxy-5-methylthiophene were released by $P$. aeruginosa but at the earliest after $24 \mathrm{~h}$ of bacteria growth.

\section{Hydrocarbons}

To our knowledge, low-molecular (C3 - C4) hydrocarbons as volatile metabolites released by pathogenic bacteria were not investigated so far. This is mostly due to technical reasons, it is impossible to analyse these compounds by direct spectrometric techniques like PTR-MS, while most of GC-MS analyses were done so far with solid phase microextraction (SPME) or sorption tubes filled with Tenax only. Tenax is not suitable to adsorb as low molecular hydrocarbons as C3 and gives very poor adsorption efficiency for C4 [36]. Therefore multibed sorption tubes were applied in the present work within which carbon molecular sieves (Carboxen 569 and Carboxen 1000) very efficiently trap the most volatile analytes (propane, butane). Consequently, the analyses of these compounds were performed at the trace level, giving the limit of detection (LOD) for propane at $33 \mathrm{ppt}_{\mathrm{v}}$ and for butane $24 \mathrm{ppt}_{\mathrm{v}}$ (data not shown).

Diverse hydrocarbons were detected mostly in low amount in the headspace of $S$. aureus and $P$. aeruginosa cultures comprising 6 and 9 different compounds, respectively. Concerning $S$. aureus solely 2-methylpropene (Figure 1e) and (E)-2-butene reached moderately high concentration levels. Intriguingly, all hydrocarbons released by $S$. aureus consist of 4 carbon atoms (except propane) while $P$. aeruginosa released larger alkenes mostly in the range of C9 - C12. Amongst all volatile metabolites released from $P$. aeruginosa hydrocarbons were one of the most important chemical classes. In particular, 1-undecene and isoprene were significantly released already at the first sampling time-point, reaching as high concentration as $\sim 300 \mathrm{ppb}_{\mathrm{v}}$ after $24 \mathrm{~h}$ of bacteria growth. Importantly concentrations of 1-undecene in headspace samples were very well correlated with the proliferation rate of $P$. aeruginosa (Figure 1f). Isoprene, the second most abundant hydrocarbon secreted by $P$. aeruginosa whose biosynthesis via methylerythritol phosphate (MEP) pathway was found in a wide range of plants and microorganisms $[37,38]$ reached the maximum concentration of $24 \mathrm{ppb}_{\mathrm{v}}$ after $24 \mathrm{~h}$ of bacteria growth. All remaining hydrocarbons were detected at low (e.g. 1-dodecene) or even extremely low concentration (e.g. 2-methyl-2-butene, 1-decene in Table 3A).

\section{Volatile nitrogen-containing compounds (VNCs)}

A smaller, but very interesting class of compounds exclusively released by $P$. aeruginosa comprised volatile nitrogen containing compounds (VNCs). The preeminent example is pyrrole, which was detected already after $1.5 \mathrm{~h}$ and reached the maximum concentration of $\sim 50 \mathrm{ppb}_{\mathrm{v}}$ after $3 \mathrm{~h}$ of bacteria growth. Interestingly, apart from 3-methylpyrrole, the VNCs had an unconventional pattern of release, reaching the maximum concentration at early time-points and continuously decreasing in the course of experiment, while they were absent in the medium control.

\section{Discussion}

The aim of this work was to investigate whether the detection and perhaps identification of bacteria can be achieved by the determination of characteristic volatile metabolites released. This work should provide the basis for the application of breath-gas analysis in the early and non-invasive diagnosis of bacterial lung infections by monitoring the presence of the specific pathogenderived markers in exhaled breath. Exhaled breath analysis is a relatively new field of research and still requires extensive basic research to evaluate the candidate compounds, which may serve as biomarkers, and to delineate their possible biochemical and cellular sources. Volatile compounds in exhaled breath may be of endogenous (i.e. derived from host cells), exogenous or microbial origin.

Hence it is crucial to investigate the contribution of microorganisms of the normal flora (originating from body compartments like the gut, upper airways, sinuses, nose or mouth) and of microorganisms expanded during infections to the VOCs found in human breath.

Numerous species which are found in normal flora of humans may also become pathogenic, e.g. when the immune system is weakened [2]. In this work two different bacterial species $[2,39]$ were investigated with respect of the release of VOCs. In the past, such or similar investigations were performed applying GC-MS, however, mostly with only qualitative and not quantitative analysis of detected VOCs $[6,7,9,10,26,40]$ or for instance with indirect quantification without calibration of VOCs of interest [30].

In our in vitro work we found that the patterns of VOC release from $S$. aureus and $P$. aeruginosa are only in part identical, and considerable differences were found concerning the dynamics of VOC production and especially the uptake of volatile metabolites. Thus, $P$. aeruginosa takes up or catabolizes (but never releases) aldehydes, in contrast to $S$. aureus, which releases high concentrations of aldehydes. Similarly, no acids were significantly released by $P$. aeruginosa in our study. Despite higher proliferation rate of $P$. aeruginosa the concentrations of released metabolites were lower from those secreted by $S$. aureus. A greater variety of volatile compounds was found in the headspace of $P$. aeruginosa as compared to $S$. aureus comprising diverse ketones, esters, sulfur containing compounds, hydrocarbons and 
additionally nitrogen containing compounds, which were not detectable in the headspace of $S$. aureus.

Zechman and co-workers have identified several identical compounds as reported here in the headspace of $S$. aureus and $P$. aeruginosa (e.g. acetoin and methylbutanal for $S$. aureus, 1-undecene and ketones for $P$. aeruginosa and DMDS and iso-pentanol for both species) using aerobic conditions similar to us with application of liquid culture and tryptic soy broth as culture medium [6]. However, they did only qualitative analyses at one incubation time point of $24 \mathrm{~h}$. Besides similarities in our study to other works, also divergent results were obtained $[6,7,11,26,30,40]$. In this respect, Scott-Thomas [26] and Labows [30] identified 2-aminoacetophenone as an important volatile metabolite of $P$. aeruginosa, which allows discrimination of cystic fibrosis patients colonized with $P$. aeruginosa from control groups (healthy subjects and CF patients colonized with other bacteria species) [26]. This compound could not be detected in the headspace of $P$. aeruginosa in our study since it is derived from tryptophan, whose concentration might be too low in the used soy based medium to form aminoacetophenone in detectable concentrations. Similarly, Allardyce et al. reported strong release of acetic acid and acetaldehyde from $P$. aeruginosa [11], whereas acetaldehyde was clearly decreasing in the Pseudomonas cultures in our study. Presumably, culture conditions (especially nutrient availability) and analytical methodologies may have a strong influence on the release of VOCs from bacteria cells, stressing the importance to standardize these factors.

Although it might be insufficient to reveal the full spectrum of potential volatile metabolites, a single growth medium (tryptic soy broth) was used for bacteria cultivation in our experiments. This medium is standard for bacteria culture ensuring fast proliferation of microorganisms. Standardization of culture conditions (e.g. proposed here application of the same medium for both species) will be a challenge for the future as bacteria differ in their requirements for nutrients and the composition of the medium in use may affect the nature of the compounds released.

The sampling of headspace gas was performed at several different time points to gain insight into the dynamics of microbial VOC production. This approach demonstrated varying VOC concentration profiles. Accurate diagnosis will require knowledge at what time after inoculation volatile metabolites show either maximum release or become steady in concentration. Although this study was limited to two species we observed specific VOC patterns for each bacterium, demonstrating the procedure developed is suitable to discriminate between pathogenic bacteria. An important issue which should be addressed in future studies is to gain insight into the VOC profiles of further clinically relevant microorganisms and to address the effect of the presence of additional pathogenic organisms in the samples as well as of the presence of host cells.

The metabolic origin of VOCs released is not completely elucidated but it is known that production of branched-chain aldehydes results from the catabolism of amino acid (Figure 2) [19,41-43]. Aldehydes then can be reduced to alcohols by alcohol dehydrogenases (e.g. 3methylbutanal to 3-methyl-1-butanol) or oxidized to carboxylic acids by an aldehyde dehydrogenase (e.g. 3-methylbutanal to isovaleric acid) as observed for $S$. aureus. Since all aforementioned compounds were found to be released by $S$. aureus in our in vitro study we presume that amino acid degradation rather than synthesis of fatty acids from alkanes is the underlying pattern of VOCs released by $S$. aureus, especially since the culture medium used in our experiments consisted mainly of amino acids, peptides and glucose. This hypothesis is also supported by other published work, where a link between availability of branched amino acids (e.g. valine, isolecine) and production of branched alcohols and aldehydes was reported [6].

Additionally, pyruvate or citrate are starting materials for the formation of short-chain flavor compounds such as acetoin, 2,3-butanedione, 1-butanol, 2-propanol, acetic acid, acetaldehyde and ethanol through glycolytic, lactate converting and non-glycolytic carbohydrates fermentations or fermentations of nitrogenous compounds [44]. The catabolism of pyruvate (presented on Figure 3) seems to play an important role in case of $S$. aureus since the products of this metabolic pathway were found in the headspace of this bacterium in our study and also by other researchers, inter alia ethanol, acetaldehyde, acetic acid [11] and acetoin [6,40].

Detailed investigation of the subspecies of the genus Staphylococcus shows that acetoin is produced by the subspecies aureus and not by the subspecies anaerobius. On the other hand, Pseudomonads are described as organisms with strictly respiratory metabolism mostly with oxygen and in some species nitrate as terminal electron acceptor [45], hence the release of alcohols and acids from these microorganisms is not expected. Indeed, carboxylic acids were not observed to be released by $P$. aeruginosa in our in vitro study, but a very week production of 2-butanol and substantially stronger of ethanol and 3-methyl-1-butanol were found. These may be related to altered activity of aldehyde- and alcoholdehydrogenase as reported by Nosova et al. [46] while the metabolism of amino acids [44] rather than glycolysis of carbohydrates via Entner-Doudoroff pathway [1] yields pyruvate as starting material under conditions applied in our study. Nevertheless, it seems that the most dominant metabolic process in $P$. aeruginosa cultures is the 


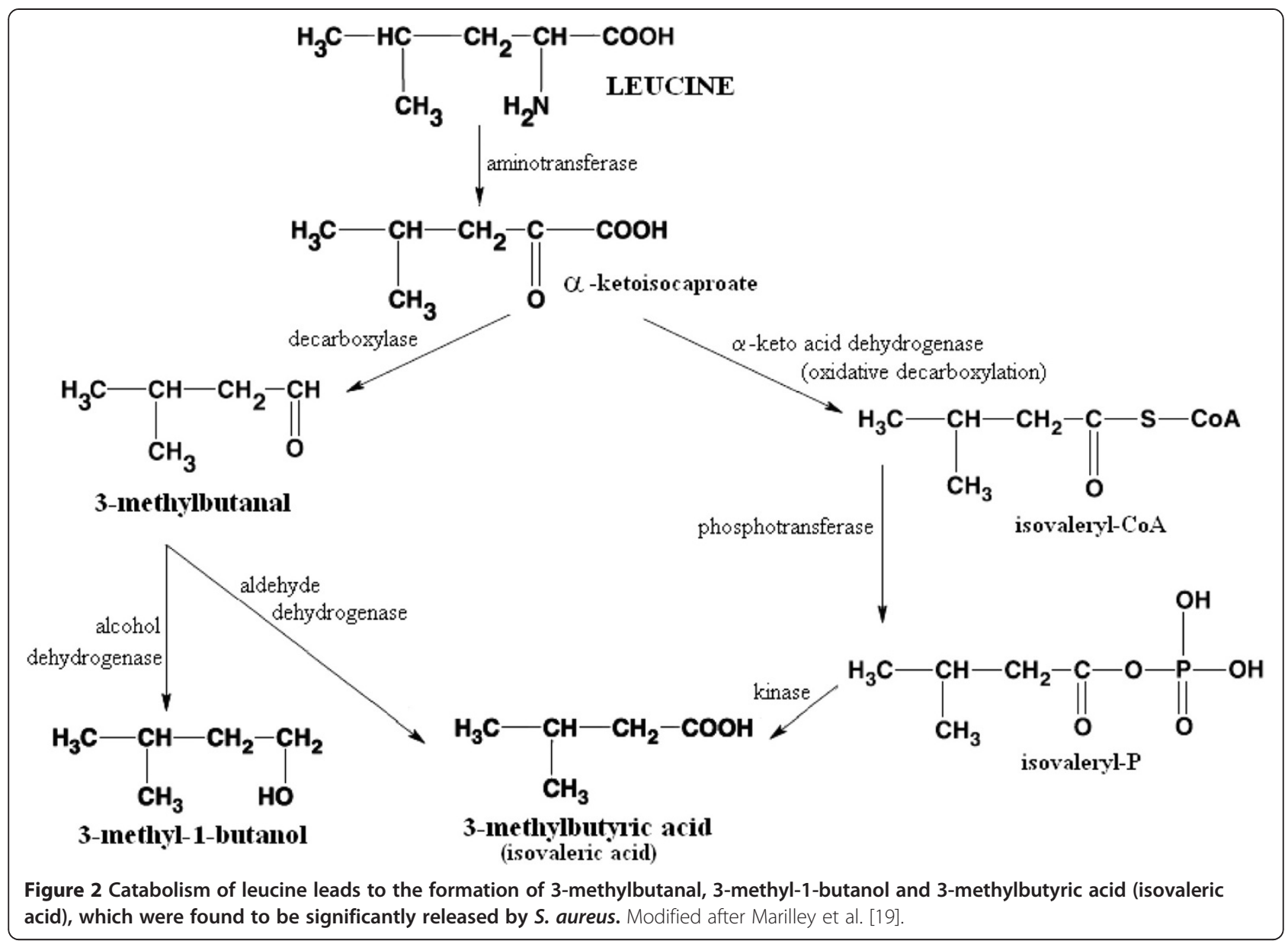

catabolism of organic compounds such as aldehydes as carbon and energy sources. The versatile nutritional requirements of Pseudomonas are commonly known and some of its subspecies utilize over 100 different compounds of diverse chemical classes what makes them particularly important organisms of bioremediation in environment (degradation of oil spills, pesticides and other xenobiotics) [1,47]. In respect to this feature, the substantial uptake of aldehydes from culture medium was observed in experiments with $P$. aeruginosa, while acetaldehyde, 3-methylbutanal, 2-methylpropanal, benzaldehyde and butanal were most strongest metabolized.

Our results confirm the production of sulfurcontaining compounds, especially by $P$. aeruginosa, extending the earlier works of other researchers $[6,7,30]$. VSCs such as dimethylsulfide, dimethyldisulfide and dimethyltrisulfide originate from auto-oxidation of methanethiol $[19,48,49]$ that can be produced though metabolism of the sulfur-containing amino acids, e.g. via demethiolation [50], transamination [51-53] or recombination pathway [54].

One of the most interesting observations in experiments with $P$. aeruginosa is the early and strong release of the nitrogen containing compounds pyrrole, 1-vinyl aziridine and 3-methylpyrrole with aberrant release patterns concerning the first two mentioned compounds compared to all other released metabolites. This finding is unique among tested bacteria species and particularly interesting from the point of view of early detection of $P$. aeruginosa infections.

Both investigated bacteria release in part the same compounds, mostly alcohols, esters and VSCs (Tables 2 and 3). As such, these compounds cannot be used for an unambiguous identification of the underlying pathogen. However, they can be used in exhaled breath analysis to monitor development of disease (e.g. emerging pneumonia), especially that some of them are released at as high concentration levels as several hundreds of $\mathrm{ppb}_{\mathrm{v}}$ (e.g. methanethiol, 3-methyl-1-butanol). Nevertheless, both bacteria $S$. aureus and $P$. aeruginosa normally do not coexist as the pathogens of pneumonia. In addition, our in vitro study clearly shows that both bacteria produce pathogen-specific metabolites allowing their identification by means of gas phase analysis. VOCs exclusively released by $S$. aureus comprise mostly low molecular weight analytes, while the compounds within the range 


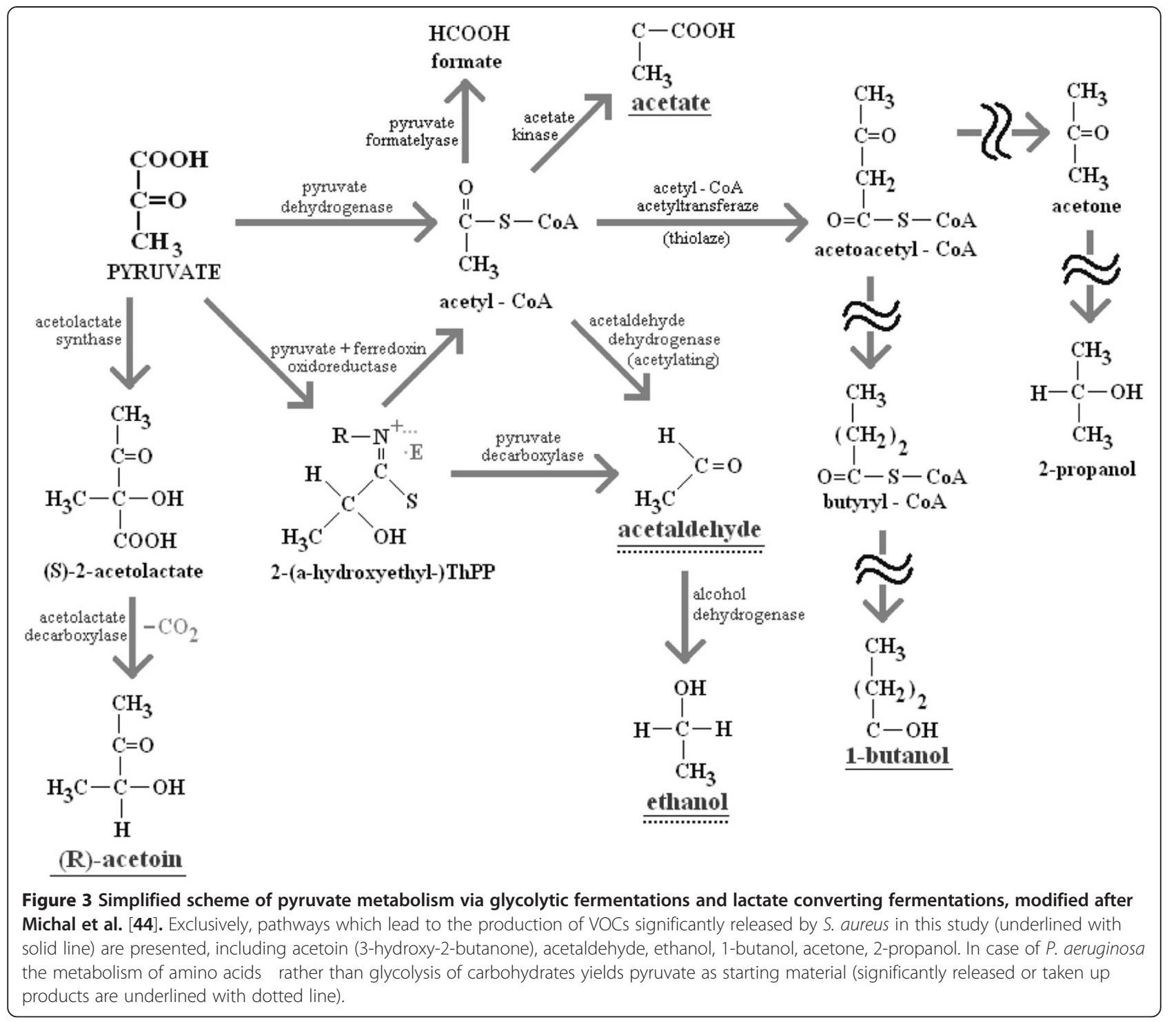

of C3 - C5 have the biggest contribution, being 76\% of all unique metabolites for this bacterium. Similarly, there is a set of metabolites exclusively released by $P$. aeruginosa. Several compounds show significantly increased concentrations already in the first few hours of bacterial growth. Among them, nitrogen-containing VOCs were released early after incubation of $P$. aeruginosa, but also ketones (besides methyl isobutyl ketone) and most of unsaturated hydrocarbons.

Compounds like acetone, isoprene, acetaldehyde and butane are normally present in human breath [55-60] resulting in substantially high background level and therefore they are unsuitable as biomarkers. We propose a candidate compound should not be present in more than $5 \%$ of healthy non-smoking subjects, ideally. Volatile metabolites fulfilling our criteria are listed in Table 4.
In this respect, particularly intriguing substances are nitrogen-containing metabolites such as 1-vinylaziridine and 3-methylpyrrole, which are increasing strongly during the first incubation phase of $P$. aeruginosa and have a decreasing tendency afterwards.

Very encouraging results were obtained also for $\alpha$ unsaturated hydrocarbons, especially 1 - undecene which was one of the most abundant VOCs produced by $P$. aeruginosa. 1-Undecene was significantly released from the first time-point of the experiment $(1.5 \mathrm{~h})$ and was never found in exhaled breath of healthy non-smokers. Interesting is also 2-nonanone, which was significantly released immediately after inoculation of $P$. aeruginosa, but never found in any exhaled breath sample. Similarly, acetoin and acetol meet all requirements for a perfect biomarker of S. aureus. 
Table 4 Maximum median concentrations [ $\mathrm{ppb}_{\mathrm{v}}$ ] with respective time of bacteria growth [h] as well as appearance in exhaled breath of healthy volunteers for selected metabolites which fulfill the criteria for biomarker of Staphylococcus aureus and Pseudomonas aeruginosa (based on in vitro experiments)
Compound
Staphylococcus aureus
Pseudomonas aeruginosa

\begin{tabular}{|c|c|c|c|c|c|c|c|c|}
\hline & \multirow[b]{2}{*}{$\begin{array}{l}\max . \text { conc. } \\
{\left[p_{p b} b_{v}\right]}\end{array}$} & \multirow[b]{2}{*}{$\begin{array}{l}\text { growth time for } \\
\text { max. conc. }\end{array}$} & \multirow[b]{2}{*}{$\begin{array}{l}\text { growth time for } \\
\text { 1st significant increase }\end{array}$} & \multirow[b]{2}{*}{$\begin{array}{l}\max . \text { conc. } \\
{\left[p_{p b}\right]}\end{array}$} & \multirow[b]{2}{*}{$\begin{array}{l}\text { growth time for } \\
\text { max. conc. }\end{array}$} & \multirow[b]{2}{*}{$\begin{array}{l}\text { growth time for } \\
\text { 1st significant increase }\end{array}$} & \multirow{2}{*}{ NON-smokers } & \multirow{2}{*}{$\begin{array}{l}\text { smokers } \\
\text { smokn }\end{array}$} \\
\hline & & & & & & & & \\
\hline 2-nonanone & n. s. & - & & 22.4 & $28 \mathrm{~h}$ & $1 \mathrm{~h} 30 \mathrm{~min}$ & 0 & 0 \\
\hline 1-nonene & n. s. & - & & 3.4 & $26 \mathrm{~h}$ & $3 \mathrm{~h} 45 \mathrm{~min}$ & 0 & 0 \\
\hline 1-decene & n. s. & - & & 1.2 & $26 \mathrm{~h}$ & $5 \mathrm{~h} 20 \mathrm{~min}$ & 0 & 0 \\
\hline 1,10-undecadiene & n. s. & - & & 6.8 & $24 \mathrm{~h}$ & $4 \mathrm{~h} 30 \mathrm{~min}$ & 0 & 0 \\
\hline 1-dodecene & n.s. & - & & 9.5 & $24 \mathrm{~h}$ & $6 \mathrm{~h}$ & 0 & 5,6 \\
\hline 1-undecene & n. s. & - & & 317.5 & $24 \mathrm{~h}$ & $1 \mathrm{~h} 30 \mathrm{~min}$ & 0 & 5,6 \\
\hline 1-vinylaziridine & n. s. & - & & $2.8 \mathrm{E}+07$ & $2 \mathrm{~h} 15 \mathrm{~min}$ & $1 \mathrm{~h} 30 \mathrm{~min}$ & 0 & 0 \\
\hline 3-methylpyrrole & n. s. & - & & 24.74 & $24 \mathrm{~h}$ & $5 \mathrm{~h} 20 \mathrm{~min}$ & 3,6 & 0 \\
\hline acetol & 331.0 & $6 \mathrm{~h}$ & $4 \mathrm{~h} 30 \mathrm{~min}$ & n. s. & - & - & 0 & 0 \\
\hline acetoin & 279.3 & $6 \mathrm{~h}$ & $1 \mathrm{~h} 30 \mathrm{~min}$ & n. s. & - & - & 3,6 & 0 \\
\hline (E)-2-butene & 13.73 & $6 \mathrm{~h}$ & $3 \mathrm{~h}$ & n. s. & - & - & 0 & 11,1 \\
\hline (Z)-2-butene & 4.789 & $6 \mathrm{~h}$ & $4 \mathrm{~h} 30 \mathrm{~min}$ & n. s. & - & - & 0 & 5,6 \\
\hline 1-butanol & 59.40 & $6 \mathrm{~h}$ & $4 \mathrm{~h} 30 \mathrm{~min}$ & n. s. & - & - & 0 & 0 \\
\hline ethyl formate & 3.188 & $6 \mathrm{~h}$ & $6 \mathrm{~h}$ & n. s. & - & - & 0 & 0 \\
\hline isopentyl acetate & 1.938 & $6 \mathrm{~h}$ & $6 \mathrm{~h}$ & n. s. & - & - & 0 & 0 \\
\hline ethyl isovalerate & 0.852 & $6 \mathrm{~h}$ & $6 \mathrm{~h}$ & n. s. & - & - & 0 & 0 \\
\hline 2-ethylacrolein & 6.453 & $3 \mathrm{~h}$ & $3 \mathrm{~h}$ & n. s. & - & - & 0 & 0 \\
\hline (Z)-2-methyl-2-butenal & 268.5 & $4 \mathrm{~h} 30 \mathrm{~min}$ & $3 \mathrm{~h}$ & n. s. & - & - & 0 & 0 \\
\hline isovaleric acid & 97.35 & $6 \mathrm{~h}$ & $4 \mathrm{~h} 30 \mathrm{~min}$ & n. s. & - & - & 0 & 5,6 \\
\hline
\end{tabular}

1 -Vinylaziridine is exclusively given as peak area due to lack of commercially available standards. Populations of healthy subjects: $n_{\text {smokers }}=23, n_{\text {non-smokers }}=32$. 


\section{Conclusions}

In conclusion, the clear differences in the bacteriaspecific profiles of VOC production were found, particularly with respect to aldehydes which were only taken up by $P$. aeruginosa and released by $S$. aureus. Considerable differences in VOCs profiles were observed also among ketones, hydrocarbons, alcohols, esters, VSCs and VNCs. The in vitro experiments were performed at bacterial densities which relate to the situation in the lungs of VAP patients, and the significant release of certain metabolites was found as early as 1.5 to 3 hours after inoculation of bacteria. Hence, our results give strong evidence that monitoring of pathogen- derived breath markers should enable non-invasive detection and perhaps even identification of virulent microorganisms causing VAP earlier than using conventional microbiological methods.

\section{Methods}

\section{Bacteria cultivation}

Staphylococcus aureus (ATCC 25923) and Pseudomonas aeruginosa (ATCC 27853) were investigated. Bacteria were inoculated in a $4 \mathrm{ml}$ liquid preculture and grown over night at $37^{\circ} \mathrm{C}$ without agitation. Both species were cultivated in tryptic soy broth medium (Merck KGaA, Darmstadt, Germany) ensuring very fast proliferation rates for the purpose of bacteria's headspace analysis by means of GC-MS. Plating for colony forming units (CFU) counts has been performed in duplicate on Mueller Hinton agar plates. $100 \mathrm{ml}$ of medium in fermenters was inoculated by adding $100 \mu \mathrm{l}$ of the preculture. As a control, tryptic soy broth medium was carried along and no other medium was tested for bacteria cultivation.

According to preliminary experiments headspace samples for GC-MS analysis were taken 1.5, 3, 4.5 and $6 \mathrm{~h}$ for $S$. aureus, respectively $1.5,2.25,3,3.75,4.5,5.25,6$, 24, 26 and $28 \mathrm{~h}$ for P. aeruginosa. Aliquots for plating of the preculture were taken at $\mathrm{t}=0 \mathrm{~h}$ and the remaining samples immediately prior to VOCs sampling time points. Samples were diluted 1:100 $\left(10^{-2}\right)$ or, if required, $1: 10000\left(10^{-4}\right)$ in $0.9 \% \mathrm{NaCl}$ and $50 \mu \mathrm{l}$ of the dilutions were plated in duplicate on Mueller Hinten agar plates using an automated spiral plater (model WASP 2, Don Whithley, Shipley, UK), revealing a detection limit of $10^{3} \mathrm{CFU} / \mathrm{ml}$. After overnight incubation at $37^{\circ} \mathrm{C} \mathrm{CFUs}$ were determined. Additionally, photometric measurements of the optical density at $600 \mathrm{~nm}$ were performed at the indicated time points to monitor bacterial proliferation. For cultivation of bacteria a previously described device was used [61-64] allowing strictly controlled ventilation and VOC sampling from four independent cultures.
Dynamic headspace sampling with simultaneous preconcentration was performed by adsorption on multibed sorption tubes as described previously [61-64].

\section{GC-MS analysis}

Composition of sorption tubes, conditions for bacteria headspace sampling, thermal desorption and calibrations as well as GC-MS settings are given elsewhere [61-64]. The temperature program of the chromatographic column was as follows: initial $55^{\circ} \mathrm{C}$ held for $6 \mathrm{~min}$, then ramped $7^{\circ} \mathrm{C} / \mathrm{min}$ up to $97^{\circ} \mathrm{C}(2 \mathrm{~min}), 2^{\circ} \mathrm{C} / \mathrm{min}$ to $110^{\circ} \mathrm{C}(0 \mathrm{~min}), 5^{\circ} \mathrm{C} / \mathrm{min}$ to $130^{\circ} \mathrm{C}(4 \mathrm{~min}), 5^{\circ} \mathrm{C} / \mathrm{min}$ to $160^{\circ} \mathrm{C}(4 \mathrm{~min}), 4^{\circ} \mathrm{C} / \mathrm{min}$ to $230^{\circ} \mathrm{C}(0 \mathrm{~min})$ and $10^{\circ} \mathrm{C} / \mathrm{min}$ to $280^{\circ} \mathrm{C}(4 \mathrm{~min})$

The constant helium flow rate of $1.8 \mathrm{ml} / \mathrm{min}$ was used as carrier gas. In addition to previous experiments, the mass spectrometer worked in a combined TIC/SIM mode. The TIC (total ion chromatogram), in the range of $m / z 20$ to $\mathrm{m} / \mathrm{z} 200$, was used for the identification of potential target compounds. Additionally, most of compounds were quantified using SIM (selective ion monitoring) mode with $100 \mathrm{~ms}$ dwell time for all ions used in SIM mode. Ions chosen for SIM monitoring of target analytes are given in Tables 2 and 3 along with the concentrations of VOCs released from bacteria cultures. The chromatographic data processing was performed by the Agilent Chemstation Software (GC-MS Data Analysis from Agilent, Waldbronn, Germany) while detected compounds were identified firstly by matching with the mass spectrum library NIST 2008 (Gaithersburg, MD, USA) and additionally confirmed with retention time of standardized reference materials. All compounds used for identification and quantification (calibration) were purchased from Sigma Aldrich (Sigma-Aldrich, Steinheim, Germany).

\section{Sampling procedure for human breath samples}

A cohort of 55 individuals (32 non-smokers, 23 activesmokers) was recruited for this study. Amongst smokers, 12 males were in the age range from 22 to 64 years and 11 females were in the age range from 21 to 65 years. The cohort of non-smokers comprised 12 males and 20 females in the age range from 22 to 87 years. All individuals gave informed consent to their participation. The volunteers completed a questionnaire describing their current smoking status (active smokers, non-smokers, ex-smokers) and the time elapsed since last smoking (if applicable). No special dietary regimes were applied. All volunteers recruited to this study were healthy, especially in respect to lung diseases caused by bacterial infections but also asthma, chronic obstructive pulmonary disease (COPD) and lung cancer. The samples were collected at different times of the day at least 2 hours 
after last meal and were processed within 6 hours after sampling.

Volunteers were asked to rest for at least 5 minutes before sampling. The alveolar air samples were collected into Tedlar bags (SKC Inc, Eighty Four, PA) by means of an in-house produced breath sampler, allowing also the collection of ambient air (also in Tedlar bags).

The device operated in two different sampling modes based on the $\mathrm{CO}_{2}$-content. Digitally controlled electronic valves switched to sampling mode if (a) the absolute level of $\mathrm{CO}_{2}$ in the breath exceeded $3 \%$ or (b) the relative level of $\mathrm{CO}_{2}$ in the breath was above $80 \%$ of the maximal $\mathrm{CO}_{2}$-level in previous exhalation. Two breath samples and respective indoor-air were collected in described above way from each subject. Before use, all bags were thoroughly cleaned to remove any residual contaminants by flushing with nitrogen 6.0 (purity of 99.9999\%), heating at $85^{\circ} \mathrm{C}$ (while filled with $\mathrm{N}_{2}$ ) for more than 8 hours and subsequent secondary flushing.

The study was approved by the local ethics committee of Innsbruck Medical University.

\section{Preparation of breath samples}

Tedlar $^{\circledR}$ bags filled with breath samples were thermostated for few minutes in an incubator at $40^{\circ} \mathrm{C}$ (to prevent condensation) and connected by means of Teflon tubes to a multibed sorption tube. The sample flow rate of $20 \mathrm{ml} / \mathrm{min}$ was diluted with additional flow $(40 \mathrm{ml} /$ min) of dry nitrogen 6.0 (additionally purified with Carboxen 1000) in order to avoid excessive adsorption of water vapor. The volume of the breath sample was $500 \mathrm{ml}$ with a total flow of $60 \mathrm{ml} / \mathrm{min}$ through the multibed sorption tube, controlled by means of mass flow regulator (RED-Y, Burde Co. GmbH, Austria). For generation of sample flow a membrane pump (Vacuubrand, Wertheim, Germany) was placed at the end of sampling system.

Additional information (e.g. composition of sorption tubes, thermal desorption GC-MS settings) is provided elsewhere [61-64].

\section{Statistical analysis}

Statistical significance was calculated by the KruskalWallis test, which is a non-parametric test to compare samples from two or more groups of independent observations [65]. P-values $<0.05$ were considered to be significant. This test was selected because it does not require the groups to be normally distributed and is more stable to outliers. To summarize the data, results are plotted as median values with $5,25,75$ and 95 percentiles. CFU counts are presented as mean values \pm standard deviation $(\mathrm{SD})$.

\section{Abbreviations}

VAP: Ventilator associated pneumonia; ICU: Intensive care unit; VOCs: Volatile organic compounds; VSCs: Volatile sulfur-containing compounds; VNCs: Volatile nitrogen-containing compounds; CFU: Colony forming units; OD: Optical density; GC-MS: Gas chromatography mass spectrometry; SIFTMS: Selected ion flow tube mass spectrometry; PTR-MS: Proton transfer reaction mass spectrometry; EN: Electronic nose; 2-AA: 2-aminoacetophenon; CF: Cystic fibrosis; BAL: Bronchoalveolar lavage; pptv: Part per trillion per

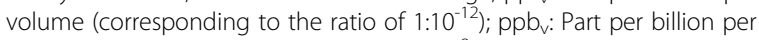

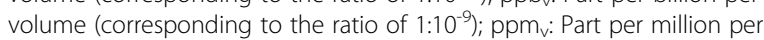
volume (corresponding to the ratio of 1:10 $0^{-6}$ ); TIC: Total ion chromatogram; SIM: Selected ion monitoring; MeSH: Methanethiol; DMS: Dimethyl sulfide; DMDS: Dimethyl disulfide; DMTS: Dimethyl trisulfide; SPME: Solid phase microextraction; LOD: Limit of detection; MEP: Methylerythritol phosphate; COPD: Chronic obstructive pulmonary disease; SD: Standard deviation.

\section{Competing interests}

Authors report no competing interests.

\section{Authors' contribution}

WF has developed the protocol for TD-GC-MS analyses of volatile compounds in headspace of cell cultures, including: conditions of sample collection, thermal desorption, GC temperature program, and mass spectrometry settings (SIM mode). Additionally, WF performed the gas chromatographic analysis of all samples, performed the calibrations, and wrote a draft of the manuscript. AS has contributed to cell culture sampling system development, performed the cell culture experiments and wrote the draft of the manuscript. MB has performed in part the cell culture experiments. AF has acquisitioned, analyzed and interpreted the chromatographic data. CA did the statistical analysis. HW has designed and constructed the system for bacteria cultivation and collection of headspace samples. MN, JT and AA have designed the study, discussed the results and finalized the manuscript. All authors read and approved the final manuscript.

\section{Acknowledgements}

The research leading to these results has received funding from the Austrian Research Promotion Agency (FFG) under project no 822696, with industrial support from Roche Diagnostics Graz GmbH. We thank Dr. Horst Rüther for initiating this project and for his continuous input and support. A.A. greatly appreciates the generous support of the government of Vorarlberg and its governor Landeshauptmann Dr. Herbert Sausgruber. The study was supported by the Austrian Science Fund, project L313-B13 (M.N.).

\section{Author details}

'Breath Research Institute of the Austrian Academy of Sciences, Rathausplatz 4, A-6850, Dornbirn, Austria. ${ }^{2}$ Univ. Clinic for Anesthesia, Innsbruck Medical University, Anichstr. 35, Innsbruck A-6020, Austria. ${ }^{3}$ Department of Hygiene, Microbiology and Social Medicine, Division of Hygiene and Medical Microbiology, Innsbruck Medical University, Fritz-Preglstraße 3, Innsbruck A-6020, Austria. ${ }^{4}$ Daniel-Swarovski Research Laboratory, Department of Visceral-, Transplant- and Thoracic Surgery, Innsbruck Medical University, Innrain 66, A-6020, Innsbruck, Austria.

Received: 24 February 2012 Accepted: 20 June 2012

Published: 20 June 2012

\section{References}

1. Madigan TM, Martinko JM, Dunlap PV, Clark DP: Brock Biology of Microorganisms. 12th edition. San Francisco: Pearson Education Inc.; 2009.

2. Goering R, Dockrell H, Zuckermann M, Wakelin D, Roitt I, Mims C, Chiodini P (Eds): Mims' Medical Microbiology. Philadelphia: Elsevier; 2008.

3. Gibson RL, Burns JL, Ramsey BW: Pathophysiology and management of pulmonary infections in cystic fibrosis. Am J Respir Crit Care Med 2003, 168(8):918-951.

4. Bercault N, Boulain T: Mortality rate attributable to ventilator-associated nosocomial pneumonia in an adult intensive care unit: a prospective case-control study. Crit Care Med 2001, 29(12):2303-2309.

5. Koulenti D, Lisboa T, Brun-Buisson C, Krueger W, Macor A, Sole-Violan J, Diaz E, Topeli A, DeWaele J, Carneiro A, et al: Spectrum of practice in the diagnosis of nosocomial pneumonia in patients requiring mechanical 
ventilation in European intensive care units. Crit Care Med 2009, 37(8):2360-2368

6. Zechman JM, Aldinger S, Labows JN Jr: Characterization of pathogenic bacteria by automated headspace concentration-gas chromatography. Chromatogr 1986, 377:49-57.

7. Scholler C, Molin S, Wilkins K: Volatile metabolites from some gramnegative bacteria. Chemosphere 1997, 35(7):1487-1495.

8. Eriksson A, Persson Waller K, Svennersten Sjaunja K, Haugen JE, Lundby F, Lind O: Detection of mastitic milk using a gas-sensor array system (electronic nose). Int Dairy J 2005, 15:1193-1201.

9. Buszewski B, Ulanowska A, Ligor T, Jackowski M, Klodzinska E, Szeliga J: Identification of volatile organic compounds secreted from cancer tissues and bacterial cultures. J Chromatogr B Analyt Technol Biomed Life Sci 2008, 868(1-2):88-94

10. Hettinga KA, van Valenberg HJ, Lam TJ, van Hooijdonk AC: Detection of mastitis pathogens by analysis of volatile bacterial metabolites. J Dairy Sci 2008, 91(10):3834-3839.

11. Allardyce RA, Langford VS, Hill AL, Murdoch DR: Detection of volatile metabolites produced by bacterial growth in blood culture media by selected ion flow tube mass spectrometry (SIFT-MS). J Microbiol Methods 2006, 65(2):361-365

12. Julak J, Stranska E, Rosova V, Geppert H, Spanel P, Smith D: Bronchoalveolar lavage examined by solid phase microextraction, gas chromatographymass spectrometry and selected ion flow tube mass spectrometry. J Microbiol Methods 2006, 65(1):76-86.

13. Scotter JM, Allardyce RA, Langford VS, Hill A, Murdoch DR: The rapid evaluation of bacterial growth in blood cultures by selected ion flow tube-mass spectrometry (SIFT-MS) and comparison with the BacT/ALERT automated blood culture system. J Microbiol Methods 2006, 65(3):628-631.

14. Bunge M, Araghipour N, Mikoviny T, Dunkl J, Schnitzhofer R, Hansel A, Schinner F, Wisthaler A, Margesin R, Mark TD: On-line monitoring of microbial volatile metabolites by proton transfer reaction-mass spectrometry. App/ Environ Microbiol 2008, 74(7):2179-2186.

15. O'Hara M, Mayhew C: A preliminary comparison of volatile organic compounds in the headspace of cultures of Staphylococcus aureus grown in nutrient, dextrose and brain heart bovine broths measured using a proton transfer reaction mass spectrometer. J Breath Res 2009, 3:027001. 027008pp.

16. Buhr K, Van Ruth S, Delahunty C: Analysis of volatile flavour compounds by proton transfer reaction mass spectrometry: fragmentation patterns and discrimination between isobaric and isomeric compounds. Int J Mass Spec 2002, 221:1-7.

17. Schwarz K, Filipiak W, Amann A: Determining concentration patterns of volatile compounds in exhaled breath by PTR-MS. J Breath Res 2009 3(2):027002.

18. Gardner JW, Craven M, Dow C, Hines EL: The prediction of bacteria type and culture growth phase by an electronic nose with a multi-layer perceptron network. Meas Sci Technol 1998, 9:120-127.

19. Marilley L, Casey MG: Flavours of cheese products: metabolic pathways, analytical tools and identification of producing strains. Int J Food Microbiol 2004, 90(2):139-159.

20. Turner AP, Magan N: Electronic noses and disease diagnostics. Nat Rev Microbiol 2004, 2(2):161-166.

21. Syhre M, Scotter JM, Chambers ST: Investigation into the production of 2 Pentylfuran by Aspergillus fumigatus and other respiratory pathogens in vitro and human breath samples. Med Mycol 2008, 46(3):209-215.

22. Liao CC, Lee CL, Chiang TC, Lee SC, Huang SH, Tu TC, Chen TK, Wu CH: The 13 C-urea breath test to detect Helicobacter pylori infection: a validated simple methodology with 50 mg 13C-urea. Aliment Pharmacol Ther 2002, 16(4):787-792

23. Eisenmann A, Amann A, Said M, Datta B, Ledochowski M: Implementation and interpretation of hydrogen breath tests. J Breath Res 2008, 2(046002).

24. Hockstein NG, Thaler ER, Torigian D, Miller WT Jr, Deffenderfer O, Hanson CW: Diagnosis of pneumonia with an electronic nose: correlation of vapor signature with chest computed tomography scan findings. Laryngoscope 2004, 114(10):1701-1705.

25. Hanson CW 3rd, Thaler ER: Electronic nose prediction of a clinical pneumonia score: biosensors and microbes. Anesthesiology 2005, 102(1):63-68.
26. Scott-Thomas AJ, Syhre S, Pattemore PK, Epton M, Laing R, Pearson J, Chambers ST: 2-Aminoacetophenone as a potential breath biomarker for Pseudomonas aeruginosa in the cystic fibrosis lung. BMC Pulm Med 2010, 10:56.

27. Mann S: Uber den Geruchsstoff von Pseudomonas aeruginosa. Arch Mikrobiol 1966, 54:184-190.

28. Mann S: Quinazoline derivatives in pseudomonads. Arch Mikrobiol 1967, 56:324-329.

29. Cox CD, Parker J: Use of 2-aminoacetophenone production in identification of Pseudomonas aeruginosa. J Clin Microbiol 1979, 9(4):479-484

30. Labows JN, McGinley KJ, Webster GF, Leyden JJ: Headspace analysis of volatile metabolites of Pseudomonas aeruginosa and related species by gas chromatography- mass spectrometry. J Clin Microbiol 1980, 12(4):521-526

31. Syhre M, Chambers ST: The scent of Mycobacterium tuberculosis. Tuberculosis (Edinb) 2008, 88(4):317-323.

32. Syhre M, Manning L, Phuanukoonnon S, Harino P, Chambers ST: The scent of Mycobacterium tuberculosis-part II breath. Tuberculosis (Edinb) 2009, 89(4):263-266

33. Chambers ST, Syhre M, Murdoch DR, McCartin F, Epton MJ: Detection of 2pentylfuran in the breath of patients with Aspergillus fumigatus. Med Mycol 2009, 47(5):468-476.

34. Chambers ST, Bhandari S, Scott-Thomas A, Syhre M: Novel diagnostics: progress toward a breath test for invasive Aspergillus fumigatus. Med Mycol 2011, 49(Suppl 1):S54-S61.

35. Anonymous: Guidelines for the management of adults with hospitalacquired, ventilator-associated, and healthcare-associated pneumonia. Am J Respir Crit Care Med 2005, 171(4):388-416.

36. Buszewski B, Ligor T, Filipiak W, Vasconcelos MT, Pompe M, Veber M: Studing of sorptive properties of systems for selective VOCs enrichment form air sample. Toxicological and Environmental Chemistry 2007, $1: 51-64$

37. Wagner WP, Helmig D, Fall R: Isoprene biosynthesis in Bacillus subtilis via the methylerythritol phosphate pathway. J Nat Prod 2000, 63(1):37-40

38. Rodriguez-Concepcion $\mathrm{M}$, Boronat $\mathrm{A}$ : Elucidation of the methylerythritol phosphate pathway for isoprenoid biosynthesis in bacteria and plastids. A metabolic milestone achieved through genomics. Plant Physiol 2002, 130(3):1079-1089.

39. Brooks G, Carroll K, Butel J, Morse S: Jawetz, Melnick \& Adelberg's Medical Microbiology. New York: The McGraw-Hill Companies; 2007.

40. Preti G, Thaler E, Hanson CW, Troy M, Eades J, Gelperin A: Volatile compounds characteristic of sinus-related bacteria and infected sinus mucus: analysis by solid- phase microextraction and gas chromatography-mass spectrometry. J Chromatogr B Analyt Technol Biomed Life Sci 2009, 877(22):2011-2018.

41. Kieronczyk A, Cachon R, Feron G, Yvon M: Addition of oxidizing or reducing agents to the reaction medium influences amino acid conversion to aroma compounds by Lactococcus lactis. J Appl Microbiol 2006, 101(5):1114-1122.

42. Morgan ME, Lindsay RC, Libbey LM, Pereira RL: Identity of additional aroma constituents in milk cultures of Streptococcus Lactis var. Maltigenes. J Dairy Sci 1966, 49(1):15-18.

43. Yvon M, Rijnen $\mathrm{L}$ : Cheese flavour formation by amino acid catabolism. Int Dairy J 2001, 11:185-201.

44. Michal G: Biochemical Pathways: An Atlas of Biochemistry and Molecular Biology. New York: John Wiley and sons, Inc; 1999.

45. Holt JG KN, Sneath PHA, Staley JT, Williams ST, et al (Eds): Bergey's Manual of Determinative Bacteriology. 9th edition. Philadelphia, PA, USA: Lippincott, Williams and Wilkins: 2000

46. Nosova T, Jokelainen K, Kaihovaara P, Heine R, Jousimies-Somer H, Salaspuro $\mathrm{M}$ : Characteristics of aldehyde dehydrogenases of certain aerobic bacteria representing human colonic flora. Alcohol Alcohol 1998, 33(3):273-280

47. Black JG: Microbiology Principles and Explorations. 7th edition. Hoboken (NJ, USA): Wiley; 2008.

48. Bonnarme P, Psoni L, Spinnler HE: Diversity of L-methionine catabolism pathways in cheese-ripening bacteria. Appl Environ Microbiol 2000, 66(12):5514-5517. 
49. McSweeney PLH, Sousa MJ: Biochemical pathways for the production of flavour compounds in cheeses during ripening: A review. Lait 2000, 80:293-324

50. Tangerman A: Measurement and biological significance of the volatile sulfur compounds hydrogen sulfide, methanethiol and dimethyl sulfide in various biological matrices. I Chromatogr B Analyt Technol Biomed Life Sci 2009, 877(28):3366-3377.

51. Amarita F, Fernandez-Espla D, Requena T, Pelaez C: Conversion of methionine to methional by Lactococcus lactis. FEMS Microbiol Lett 2001 204(1):189-195.

52. Levitt MD, Furne J, Springfield J, Suarez F, DeMaster E: Detoxification of hydrogen sulfide and methanethiol in the cecal mucosa. J Clin Invest 1999, 104(8):1107-1114.

53. Furne J, Springfield J, Koenig T, DeMaster E, Levitt MD: Oxidation of hydrogen sulfide and methanethiol to thiosulfate by rat tissues: a specialized function of the colonic mucosa. Biochem Pharmacol 2001, 62(2):255-259.

54. Troccaz M, Benattia F, Borchard G, Clark AJ: Properties of recombinant Staphylococcus haemolyticus cystathionine beta-lyase (metC) and its potential role in the generation of volatile thiols in axillary malodor. Chem Biodivers 2008, 5(11):2372-2385.

55. Amann A, Ligor M, Ligor T, Bajtarevic A, Ager C, Pienz M, Denz H, Fiegl M, Hilbe W, Weiss W, et al: Analysis of exhaled breath for screening of lung cancer patients. MEMO 2010, 3:103-112.

56. Bajtarevic A, Ager C, Pienz M, Klieber M, Schwarz K, Ligor M, Ligor T, Filipiak W, Denz H, Fiegl M, et al: Noninvasive detection of lung cancer by analysis of exhaled breath. BMC Cancer 2009, 9:348.

57. Kushch I, Arendacka B, Stolc S, Mochalski P, Filipiak W, Schwarz K, Schwentner L, Schmid A, Dzien A, Lechleitner M, et al: Breath isoprene aspects of normal physiology related to age, gender and cholesterol profile as determined in a proton transfer reaction mass spectrometry study. Clin Chem Lab Med 2008, 46:1011-1018.

58. Schwarz K, Pizzini A, Arendacká B, Zerlauth K, Filipiak W, Schmid A, Dzien A Neuner S, Lechleitner M, Scholl-Bürgi S, et al: Breath acetone - aspects of normal physiology related to age and gender as determined in a PTRMS study. J Breath Res 2009, 3:027003. 027009 pp.

59. Amann A, Spanel P, Smith D: Breath analysis: the approach towards clinical applications. Mini Rev Med Chem 2007, 7:115-129.

60. Amann A, Poupart G, Telser S, Ledochowski M, Schmid A, Mechtcheriakov S: Applications of breath gas analysis in medicine. Int I Mass Spectrometry 2004, 239:227-233.

61. Filipiak W, Sponring A, Mikoviny T, Ager C, Schubert J, Miekisch W, Amann A, Troppmair J: Release of volatile organic compounds (VOCs) from the lung cancer cell line CALU-1 in vitro. Cancer Cell Int 2008, 8:17.

62. Sponring A, Filipiak W, Mikoviny T, Ager C, Schubert J, Miekisch W, Amann A, Troppmair J: Release of volatile organic compounds from the lung cancer cell line NCI-H2087 in vitro. Anticancer Res 2009, 29(1):419-426.

63. Sponring A, Filipiak W, Ager C, Schubert J, Miekisch W, Amann A, Troppmair $\mathrm{J}$ : Analysis of volatile organic compounds (VOCs) in the headspace of $\mathrm{NClH1666}$ lung cancer cells in vitro. Cancer Biomark 2010, 7:1-9.

64. Filipiak W, Sponring A, Filipiak A, Ager C, Schubert J, Miekisch W, Amann A Troppmair J: TD-GC-MS analysis of volatile metabolites of human lung cancer and normal cells in vitro. Cancer Epidemiol Biomarkers Prev 2010, 19(1):182-195.

65. Kleinbaum D, Kupper L, Muller A, Nizam K: Applied Regression Analysis and Other Multivariable Methods. Pacific Grove (CA): Brooks/Cole Publishing Company; 1998.

doi:10.1186/1471-2180-12-113

Cite this article as: Filipiak et al:: Molecular analysis of volatile metabolites released specifically by staphylococcus aureus and pseudomonas aeruginosa. BMC Microbiology 2012 12:113.

\section{Submit your next manuscript to BioMed Central and take full advantage of:}

- Convenient online submission

- Thorough peer review

- No space constraints or color figure charges

- Immediate publication on acceptance

- Inclusion in PubMed, CAS, Scopus and Google Scholar

- Research which is freely available for redistribution

Submit your manuscript at www.biomedcentral.com/submit 